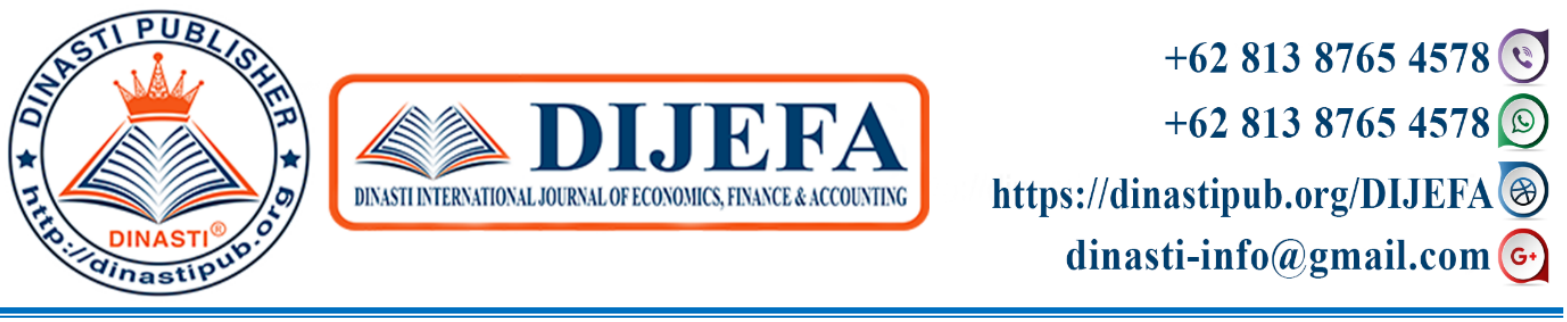

\title{
COST OF DEBT: THE IMPACT OF FINANCIAL FACTORS AND NON- FINANCIAL FACTORS
}

\section{Angela Dirman}

Universitas Mercu Buana, Jakarta, Indonesia

\begin{tabular}{|c|c|}
\hline $\begin{array}{c}\text { ARTICLE INFORMATION } \\
\text { Received: } 8 \text { August } 2020 \\
\text { Revised: } 28 \text { August } 2020 \\
\text { Issued: 23 September } 2020 \\
\text { Corresponding author: first } \\
\text { author } \\
\text { E-mail: } \\
\text { angela.dirman@mercubuana.ac.id } \\
\end{array}$ & $\begin{array}{l}\text { Abstract: The research objective to be achieved is to provide } \\
\text { understanding and knowledge to the public, especially } \\
\text { investors and creditors regarding the implications of } \\
\text { corporate financial and non-financial factors on cost of debt } \\
\text { and can be used as a reference for further researchers as well } \\
\text { as a reference for stakeholders (investors, creditors and } \\
\text { government) in taking relevant and reliable decisions. The } \\
\text { method used is quantitative research with secondary data } \\
\text { taken from the financial statements of issuers at IDX with } \\
\text { data collection techniques using purposive sampling method. } \\
\text { The data analysis used is multiple linear regression. The } \\
\text { population in this study were manufacturing companies in the } \\
\text { basic industry and chemical sectors listed on the Indonesia } \\
\text { Stock Exchange which were carried out for } 3 \text { years of } \\
\text { observation, namely 2016-2018. The sample was determined } \\
\text { by purposive sampling method in order to obtain as many as } \\
\text { 60 samples. The analysis technique used is the t statistical test } \\
\text { and the classical assumption test which includes the } \\
\text { normality test, multicollinearity test, heteroscedasticity test, } \\
\text { and autocorrelation test. The results of this study indicate that } \\
\text { the leverage variable has a positive effect on cost of debt; the } \\
\text { variables of profitability, liquidity, managerial ownership, } \\
\text { institutional ownership, and independent commissioners did } \\
\text { not affect the cos of debt. } \\
\text { Keywords: Profitability, Liquidity, Leverage, Managerial } \\
\text { Ownership, Institutional Ownership, Independent } \\
\text { Commissioner, Cost of debt }\end{array}$ \\
\hline
\end{tabular}

\section{INTRODUCTION}

The company has several alternatives in financing, one of which is by using debt. Debt is one way of obtaining funds from external parties, namely creditors. Funds provided by creditors in terms of financing the company incur debt costs for the company. The cost of debt (Cost of Debt) can be interpreted as the rate of return expected by creditors when funding in a 
company (Meiriasari, 2017). Debt costs also include the interest rate that must be paid by the company when making a loan. The company's ability to manage debt costs is needed. The accumulation of debt and the inability to pay loans to creditors is the cause of the financial crisis and bankruptcy experienced by many companies (Awaloedin \& Nugroho, 2019).

The global economic crisis in 2008 which began in the United States economic crisis which then spread to other countries around the world including Indonesia, one of the causes was due to the accumulation of debt (debt). One of the companies that was declared bankrupt due to accumulated debt was PT Citra Maharlika Nusantara Corpora Tbk. (Cipaganti). The company previously named PT Cipaganti Citra Graha Tbk was declared bankrupt on April 27, 2017 because the peace proposal was rejected by the majority of creditors. This bankruptcy case also stems from the PKPU Cipaganti status since October 31, 2016. The company's total debt amounts to IDR245 billion.

Another case that befell a company listed on the IDX is PT. Berau Coal Energy, which was sued for bankruptcy by creditors because it failed to pay off maturing debts. PT. Berau Coal Energy Tbk has defaulted its US \$ 450 bond debt maturing on July 8, 2015. The 12.5 percent coupon bond was issued by Berau Resources Pte Ltd in Singapore and guaranteed by PT. Berau Coal Energy Tbk. Another case is PT Dwi Aneka Jaya Kemasindo Tbk. (DAJK). This cardboard and paper packaging company officially went bankrupt on November 22, 2017 after the panel of judges granted the request to cancel the peace filed by Bank Mandiri.

Juniarti \& Sentosa (2009) state that in the condition of companies with high debt costs, the company tries to cover up the actual condition of the company so that there is no decline in stock prices. On the other hand, investors need adequate disclosure to ensure whether their investment has risks in accordance with what is expected. The investors' demands prompted the company to disclose financial reports more broadly. Information disclosed by companies voluntarily can be seen from the level of risk the company has (Yunita, 2012). Information on financial factors can be obtained through financial reports. The financial statements issued by the company are an illustration of the company's financial performance. The overall purpose of financial reports is to provide useful information for investors and creditors in making investment and credit decisions. The types of decisions made by decision makers vary widely, as are the decision-making methods that companies use and the company's ability to process 
information (Hery, 2015). Investors and creditors often use information from financial reports as a benchmark in making investment decisions.

On the other hand, Randa dan Solon (2012) stated that for investors and creditors, information on financial factors from financial reports alone is not sufficient to make investment decisions. Investors and creditors also need information on non-financial factors in determining investment decisions. Companies must strengthen non-financial factors in order to keep growing and survive. One of the non-financial factors is that the company can make improvements in management to increase work effectiveness and efficiency. Companies need performance monitoring from the management of the company, namely by implementing good corporate governance. The implementation of corporate governance is expected to increase supervision of management to encourage effective decision making, prevent opportunistic actions that are not in line with company interests, and reduce information asymmetry between executives and company stakeholders. Thus, the implementation of corporate governance (CG) by companies can affect the level of debt.

Ashbaugh-Skaife, Collins, dan LaFond (2006) research shows that companies with strong CG have higher credit ratings than companies with weak CG. Credit ratings will affect the perceptions of creditors and potential creditors of a company's credibility and ability to meet its overall financial obligations. Thus, it is clear that with a high rating, a company with strong CG will enjoy a lower cost of debt. Chen and Jian (2006) in Ashkhabi (2015) state that a healthy corporate governance structure is one of the important indicators that creditors consider when determining a company's risk premium. Corporate governance mechanisms cover many things, for example the number of managerial ownership, institutional ownership, and independent commissioners. With one of these GCG mechanisms, it is hoped that the monitoring of company managers will be more effective so that it can improve company performance and reduce the cost of debt.

\section{LITERATURE REVIEW}

\section{Agency Theory}

According to Jensen \& Meckling (1976) agency relationships are the source of contracts between managers (agents) and investors (principle). Principals are shareholders or investors, while agents are management who manage the company or manager. The essence 
of the agency relationship is the separation of functions between ownership in investors and control on the part of management. The conflict of interest between the principle and the agent occurs because the agent may not always act in accordance with the principle's interests, resulting in agency costs.

Agency theory assumes that all individuals act in their own interests. The principal wants the maximum possible return on the capital invested. Meanwhile, the manager as an agent wants his interests to be fulfilled by providing compensation, bonuses, incentives and as much remuneration as possible for his performance. Thus, there arises a conflict of interest between principals and agents (Azis, 2014).

Regarding agency theory, this research relates to agency theory related to Good Corporate Governance (GCG) because it highlights the direct relationship between principal and agent (Lestari \&Priyadi, 2017). The agency relationship perspective is the basis used to understand corporate governance. Agency theory results in an asymmetrical relationship between owners and managers, to avoid an asymmetric relationship, a concept is needed, namely the concept of Good Corporate Governance which aims to make the company healthier (Windasari \& Riharjo, 2017).

\section{The Effect of Profitability on the Cost of Debt}

Return on Asset is a measurement that can be used to assess a company's profitability. Profitability Ratios determine the decision to use debt for corporate funding. Companies with a high level of profitability generally use debt in relatively small amounts because with high rates of return on investment companies can make capital with retained eranings (Purba, 2011 in Sherly \& Fitria, 2019). The use of low debt causes the cost of debt incurred to be low. The measurement results of ROA (Return on Asset) are often used as a means of measuring a company's financial performance to find out how efficient the management of capital is on its assets. The greater the value of ROA of a company, the greater the level of profits derived by the company and also the company's position in terms of the use of assets, so as to reduce the cost of debt. In Sherly \& Fitria (2019) study, which examined the effect of profitability on the cost of debt, it was found that profitability had a negative effect on cost of debt. From this explanation, the hypothesis is obtained:

H1: Profitability has a negative effect on cost of debt 


\section{Effect of Liquidity on the Cost of Debt}

Liquidity ratios are used to describe how liquid a company is and the company's ability to settle short-term liabilities using current assets. In other words, this ratio is used to measure the company's ability to pay obligations that are due immediately (Kasmir, 2008: 129). Agustina (2013) explains that companies that have a high level of liquidity indicate that the company tends to have high growth opportunities. The more liquid the company is, the lower the debt costs that must be paid by the company. From this explanation, the hypothesis is obtained:

H2: Liquidity has a negative effect on the cost of debt

\section{Effect of Leverage on Cost of Debt}

Leverage is a ratio that describes the relationship between the company's debt to capital, this ratio can see how far the company is financed by debt or outsiders with the company's ability as described by capital. Sources of funding within the company can be obtained from internal and external companies. From internal companies can be in the form of retained earnings and external companies in the form of debt or the issuance of new shares. Companies that use debt are liable for interest expense and loan principal expense. The use of debt (external financing) has a large enough risk of not repaying the debt, so the use of debt needs to pay attention to the company's ability to generate profits. Leverage can be understood as an estimator of the risks inherent in a company, meaning that greater leverage indicates greater investment risk (Prasetyorini, 2013). In Awaloedin dan Nugroho (2019) the debt ratio has a positive effect on the cost of debt. From this explanation, the hypothesis is obtained:

H3: Leverage has a positive effect on cost of debt

\section{The Effect of Managerial Ownership on the Cost of Debt}

Managerial ownership is the shareholder of the manager. Companies with managerial ownership will certainly align their interests. Because the manager who acts as an agent also owns shares in the company, so the manager will do things that are certainly not detrimental to the company because what will happen to the company will also affect or affect them. With managerial ownership in a company, managers will be more careful in making decisions 
related to debt policy. Managers will reduce the amount of debt to minimize the risk that might occur which will also have an impact on creditors' decisions in determining the determined rate of return. The smaller the risk the company has, the creditors have a higher level of confidence, which affects the rate of return to be determined. The desire to improve the company's performance makes management try to make it happen. Therefore, the greater the ownership of the manager, the smaller the cost of company debt because the manager will feel the impact and risk of the company. The results of Juniarti dan Sentosa (2009) and Swissia \& Purba (2018) show that the proportion of managerial ownership has a negative effect on the cost of debt. From the explanation, the following hypothesis is obtained:

H4: Managerial ownership is negative for cost of debt

\section{The Effect of Institutional Ownership on the Cost of Debt}

Institutional ownership is the percentage of company share ownership owned by institutional investors. With a significant amount of institutional ownership outside the company, it will cause parties outside the company to exercise strict supervision of the management carried out by management. For management, outside supervision encourages them to show better performance, and conducts management transparently. Institutional investors are believed to have the ability to monitor management actions better than individual investors, where institutional investors will not be easily deceived by manipulating actions by management (Rachmawati and Triatmoko (2007) in Kistiah \& Mudjiyanti (2014).

Roberts and Yuan (2009) suggest that institutional ownership can significantly reduce the cost of debt, because large institutional ownership makes parties outside the company carry out more stringent supervision or monitoring of management so that management is encouraged to improve company performance and can prevent fraud that occurs. will be carried out by the manager. And with the existence of tight supervision can make the company's performance be good, so that creditors see the company's risk is low. Thus, institutional ownership can reduce the cost of debt incurred by the company. Research by Swissia \& Purba (2018) that institutional ownership has a significant negative effect on the cost of debt. From this explanation, the hypothesis is obtained:

H5: Institutional ownership is negative for cost of debt 


\section{The Effect of Independent Commissioners on the Cost of Debt}

The existence of an independent commissioner element in the company's organizational structure that comes from outside the company serves to balance decision making, especially in the context of protecting minority shareholders and other related parties. An independent commissioner can function to oversee the running of a company by ensuring that the company has implemented practices of transparency, disclosure, independence, accountability and fairness practices according to the prevailing regulations in a country's economic system. The existence of independent commissioners in a company can affect the integrity of a financial report produced by management. If the company has independent commissioners, the financial statements presented by management tend to have more integrity, because within the company there is a body that oversees and protects the rights of parties outside the company's management and makes management performance better. Good management performance can reduce company risk. The results of research by Septian dan Panggabean (2017) state that the proportion of independent commissioners has a negative effect on the cost of debt.

H6: Independent Commissioners have a negative effect on cost of debt

\section{Previous Research}

In Awaloedin \& Nugroho (2019) entitled research The Effect of Company Size, Debt Ratio, and Company Age on Debt Costs, the research sample is manufacturing companies listed on the Indonesia Stock Exchange 2015-2017. Based on the results of the analysis that has been done, it is found that firm size has no effect on debt costs, debt ratios have an effect on debt costs, and company age has no effect on debt costs.

In Pernamasari (2018) entitled research Application of Good Corporate Governance and Earning Management to Cost of Debt at BUMN Companies CGPI Listing 2010-2012. The results show that institutional ownership in this case the government as the largest shareholder has an influence on the size and size of debt costs. , the GCG index has no effect on the cost of debt of BUMN companies, there is no influence of corporate governance on the cost of debt, and earnings management has an effect on the value of debt.

In Saputra \& Faizal (2016) entitled research The Influence of Corporate Governance Perception Index, Managerial Ownership, Government Ownership and Sales Growth on Cost 
of Debt (Study in Non-Financial Companies Listed on IDX Year 2011-2014) based on the results of the analysis that has been It was found that the corporate governance perception index, managerial ownership, government ownership, and sales growth simultaneously influenced the cost of debt in non-financial companies listed on IDX year 2011-2014. The corporate governance perception index does not influence the cost of debt in non-financial companies listed on IDX year 2011-2014. The managerial ownership influences the cost of debt in non-financial listed on IDX year 2011-2014. The government ownership does not influence the cost of debt in non-financial companies listed on IDX year 2011-2014. The sales growth does not influence the cost of debt in non-financial companies listed on IDX year 20112014.

\section{RESEARCH METHOD}

\section{Definition and Operationalization of Variables Dependent variable}

Cost of debt is calculated from the amount of interest expense paid by the company in a period of one year divided by the average number of loans that generate this interest. The formula used to calculate the cost of debt (COD) is:

$\mathrm{COD}=\underline{\text { Interest expense }}$

Average interest bearing debt

\section{Independent Variable}

\section{Profitability}

Profitability Ratios are ratios to assess a company's ability to look for profits or profits for a certain period. The ratio used in this study is Return on Assets (ROA) with calculations (Kasmir, 2019):

\section{ROA $=$ Net Profit $/$ Total Assets}

\section{Liquidity}

Liquidity ratio is the ratio used to measure how liquid a company is (Kasmir, 2012: 130). The formula of the Current ratio (Syamsuddin, 2011: 43):

Current Ratio $=\quad$ Current Asset Current Liabilities

\section{Leverage}


The Solvency Ratio is a ratio used to measure the extent to which a company's assets are financed with debt. The ratio used in this study is Debt to equity ratio (DER) with calculations (Kasmir, 2019):

$$
\text { DER }=\frac{\text { Total Debt }}{\text { Equity }}
$$

\section{Managerial Ownership}

Managerial ownership is the percentage of shares owned by management that actively participates in corporate decision making which includes ownership by directors (Fitdini, 2009 in Nur \& Yuyetta, 2019) The existence of managerial ownership in the company can be one of the efforts in reducing agency problems with managers and aligning interests between managers and shareholders. In this study managerial ownership is measured by the percentage of shares owned by the company's management of the total number of shares outstanding. The formula for calculating the percentage of managerial ownership based on Sartono's (2010) research in D \& Suartana (2014) is as follows:

$$
\text { Managerial ownership }=\frac{\text { Total of managerial shares }}{\text { total of outstanding share }}
$$

\section{Institutional Ownership}

Institutional ownership is ownership of shares by investors in the form of non-bank financial institutions / institutions that manage funds on behalf of others. In this study institutional ownership is measured by the number of institutional shares in relation to the number of shares outstanding. Institutional ownership can be formulated as follows D \& Suartana (2014):

$$
\text { Institutional ownership }=\frac{\text { Total of institutional share }}{\text { total of outstanding share }}
$$

\section{Independent Commissioner}

An independent commissioner is a member of a board of commissioners who does not have a relationship that can affect his ability to act independently (Hanifah \& Purwanto, 2013). The independent commissioner variable is measured by proportion. The proportion of independent commissioners is calculated by: 


$$
\text { Proportion of independent commissioners }=\frac{\text { Total of independent commissioners }}{\text { total of commissiners }}
$$

\section{Population and Research Samples}

The population of this study is companies listed on the Indonesia Stock Exchange. The sample used in this study is industrial and chemical manufacturing companies listed on the Indonesia Stock Exchange in 2016-2018. The sampling method used was purposive sampling, namely sampling based on the criteria for companies listed on the IDX and not delisted during 2016-2018, the company's financial statements are presented in Rupiah so that they can be compared between periods and between companies, the company has a structure institutional ownership, has managerial ownership, and the company has interest bearing debt, both short and long term.

\section{Analysis Method}

In testing the hypothesis proposed in this study. The researcher uses the method of multiple linear regression analysis because of the relationship between two or more independent variables where previously the classical assumptions were made in the first stage.

\section{Classical Assumption Test}

This analysis can also be referred to as a prerequisite test of the multiple linear regression model to be tested. A good regression model must produce the best unbiased linear estimator (Best Linear Unbias Estimator / BLUE). This condition will occur if it is fulfilled by several assumptions called classical assumptions including normality test, multicollinearity test, heteroscedasticity test, autocorrelation test.

The regression model in this study is stated as follows:

$$
\mathrm{COD}=\mathrm{a}+\beta 1 \mathrm{ROA}+\beta 2 \mathrm{CR}+\beta 3 \mathrm{DER}+\beta 4 \text { Kep.Manj }+\beta 5 \text { Kep.Ins }+\beta 6 \text { Kom.Indp }+\mathrm{e}
$$

\section{Results and Discussion}

\section{Results}

\section{a. Classical Assumption Test}




\section{Normality test}

Kolmogorov-Smirnov One Sample Results

One-Sample Kolmogorov-Smirnov Test

\begin{tabular}{|c|c|c|}
\hline & & $\begin{array}{c}\text { Unstandar } \\
\text { dized } \\
\text { Residual }\end{array}$ \\
\hline $\begin{array}{l}\text { N } \\
\text { Normal Parameters }{ }^{a, b} \\
\text { Most Extreme } \\
\text { Differences } \\
\text { Kolmogorov-Smirnov Z } \\
\text { Asymp. Sig. (2-tailed) }\end{array}$ & $\begin{array}{l}\text { Mean } \\
\text { Std. } \\
\text { Deviation } \\
\text { Absolute } \\
\text { Positive } \\
\text { Negative }\end{array}$ & $\begin{array}{r}60 \\
0 \mathrm{E}-7 \\
1,4401274 \\
6 \\
, 163 \\
, 163 \\
-, 092 \\
1,265 \\
, 081\end{array}$ \\
\hline
\end{tabular}

a. Test distribution is Normal.

b. Calculated from data.

The table above shows that the Kolmogorov-Smirnov value is 1,265 and the Asymp value. Sig. (2-tailed) of 0.081. Because the Asymp value. Sig is greater than the significance level of $0.05(0.081>0.05)$, it can be concluded that the residual data in this regression model is normally distributed.

\section{Multicollinearity Test}

There is no multicolliniarity among the independent variables. Then there is no multicolliniarity between the independent variables.

\section{Heteroskedaticity Test}

The profitability, liquidity, leverage, managerial ownership, institutional ownership, and independent commissioners variables in the heteroscedasticity test show that there was no heteroscedasticity, it can be seen from the sig value of each variable more than 0.05.

\section{Autocorrelation Test}

Then there is no autocorrelation between the independent variables.

\section{Hypothesis testing}

\section{Determination Coefficient Test}

\begin{tabular}{|c|r|r|r|r|r|}
\hline $\begin{array}{c}\text { M } \\
\text { od } \\
\text { el }\end{array}$ & $\mathrm{R}$ & $\mathrm{R}$ & $\begin{array}{c}\text { Adjusted R } \\
\text { Squar } \\
\mathrm{e}\end{array}$ & $\begin{array}{c}\text { Std. Error } \\
\text { of the } \\
\text { Estimate }\end{array}$ & $\begin{array}{c}\text { Durbin- } \\
\text { Watson }\end{array}$ \\
\hline 1 &, $724^{\mathrm{a}}$ &, 524 &, 470 & 1,5194590 & 2,276 \\
\hline
\end{tabular}


a. Predictors: (Constant), Komisaris Independen, Kepemilikan Manajerial, CR, DER, ROA, Kepemilikan Institusional

b. Dependent Variable: COD

The table above shows that the coefficient of determination which shows the R-square value is 0.524 . This means that $52.4 \%$ of the variation in cost of debt can be explained significantly by variations in ROA, CR, DER, managerial ownership, institutional ownership, and independent commissioners, while $(100 \%-52.4 \%)=47.6 \%$ total cost of debt can be explained by other variables.

\section{F Test}

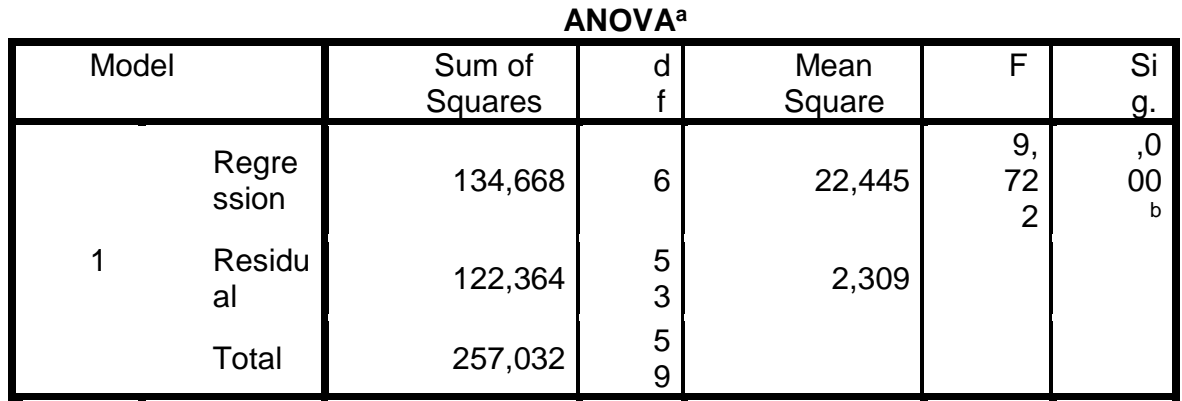

a. Dependent Variable: COD

b. Predictors: (Constant), KomisarisIndependen, KepemilikanManajerial, CR, DER, ROA, KepemilikanInstitusional

Based on the data above, a significant value of 0,000 is obtained. Because the significance is less than 0.05 or $5 \%$, thus Ho is rejected and Ha is accepted, it can be concluded that profitability, liquidity, leverage, managerial ownership, institutional ownership and independent commissioners have an effect on the cost of debt.

\section{T Test}

\section{Coefficients $^{\mathrm{a}}$}

\begin{tabular}{|c|c|c|c|c|c|c|c|}
\hline \multirow[t]{2}{*}{ Model } & \multicolumn{2}{|c|}{$\begin{array}{c}\text { Unstandardized } \\
\text { Coefficients }\end{array}$} & \multirow{2}{*}{\begin{tabular}{|c}
$\begin{array}{c}\text { Standardized } \\
\text { Coefficients }\end{array}$ \\
Beta
\end{tabular}} & \multirow[t]{2}{*}{$\mathrm{t}$} & \multirow[t]{2}{*}{ Sig. } & \multicolumn{2}{|c|}{$\begin{array}{l}\text { Collinearity } \\
\text { Statistics }\end{array}$} \\
\hline & $B$ & Std. Error & & & & Tolerance & VIF \\
\hline (Constant) & $-1,530$ & 1,564 & &,- 978 & ,333 & & \\
\hline $\mathrm{ROA}$ & 1,047 & 4,279 & ,026 & 245 & ,808 & ,803 & 1,245 \\
\hline $\mathrm{CR}$ & ,002 & ,222 &, 001 & ,008 & ,994 & ,791 & 1,263 \\
\hline DER & 1,708 & 249 & ,715 & 6,869 &, 000 & ,828 & 1,208 \\
\hline
\end{tabular}




\begin{tabular}{l|r|r|r|r|r|r|r|}
\hline KepemilikanManajerial &,- 889 & 1,646 &,- 070 &,- 540 &, 592 &, 535 & 1,870 \\
KepemilikanInstitusional &,- 095 & 1,030 &,- 012 &,- 092 &, 927 &, 503 & 1,989 \\
KomisarisIndependen & 3,137 & 3,242 &, 094 &, 967 &, 338 &, 952 & 1,051 \\
\hline
\end{tabular}

a. Dependent Variable: COD

From the above test results it can be concluded as follows:

1. This shows that ROA has no effect on Cost of Debt

2. This shows that CR has no effect on Cost of Debt

3. This shows that DER has a negative effect on Cost of Debt

4. This shows that managerial ownership has no effect on Cost of Debt

5. This shows that institutional ownership has no effect on Cost of Debt

6. This shows that independent commissioner has no effect on Cost of Debt

Multiple Regression Analysis Test Results

Coefficients $^{\mathrm{a}}$

\begin{tabular}{|c|c|c|c|c|c|c|c|}
\hline \multirow[t]{2}{*}{ Model } & \multicolumn{2}{|c|}{$\begin{array}{c}\text { Unstandardized } \\
\text { Coefficients }\end{array}$} & \multirow{2}{*}{\begin{tabular}{|c|}
$\begin{array}{c}\text { Standardized } \\
\text { Coefficients }\end{array}$ \\
Beta \\
\end{tabular}} & \multirow[t]{2}{*}{$\mathrm{t}$} & \multirow[t]{2}{*}{ Sig. } & \multicolumn{2}{|c|}{$\begin{array}{l}\text { Collinearity } \\
\text { Statistics }\end{array}$} \\
\hline & $\mathrm{B}$ & Std. Error & & & & Tolerance & VIF \\
\hline (Constant) & $-1,530$ & 1,564 & &,- 978 & ,333 & & \\
\hline ROA & 1,047 & 4,279 & ,026 & 245 & 808 & ,803 & 1,245 \\
\hline CR & ,002 & ,222 & 001 & ,008 & ,994 & ,791 & 1,263 \\
\hline 1 DER & 1,708 & ,249 & ,715 & 6,869 &, 000 & ,828 & 1,208 \\
\hline KepemilikanManajerial &,- 889 & 1,646 &,- 070 &,- 540 & ,592 &, 535 & 1,870 \\
\hline KepemilikanInstitusional &,- 095 & 1,030 &,- 012 &,- 092 & ,927 &, 503 & 1,989 \\
\hline KomisarisIndependen & 3,137 & 3,242 & ,094 & ,967 & ,338 & ,952 & 1,051 \\
\hline
\end{tabular}

a. Dependent Variable: COD

Based on the table of multiple linear regression test results, the regression equation is obtained as follows: Cost of debt $=-1,530+1,047 \mathrm{ROA}+0,002 \mathrm{CR}+1,708 \mathrm{DER}+(-0,889$ KepMen $)+(-0,095$ KepInst $)+3,137$ KomInd + e

\section{Discussion}

\section{Effect of Profitability on Cost of Debt}

The test results show that profitability as measured by return on assets has no effect on the cost of debt. That is, the higher or lower the ratio of return of assets does not affect the cost of debt. Return On Asset is a measurement that can be used to assess a company's profitability. 
Profitability Ratios determine the decision to use debt for corporate funding. Companies with a high level of profitability generally use debt in relatively small amounts because with high rates of return on investment companies can make capital with retained eranings (Purba, 2011 in Sherly \& Fitria, 2019). But in this study, profitability does not affect the cost of debt, this is because the sample companies prefer to use their own capital (internal funds) rather than the use of debt. Internal funding chosen by the company causes the company to use low external funds or not even use external funding at all in the form of debt. And if there is a sample company that uses debt to develop its business, the debt does not interfere with existing performance because it can be directly covered by their assets.

\section{The Effect of Liquidity on the Cost of Debt}

The test results show that the liquidity proxied by the current ratio has no effect on the cost of debt. This means that the higher or lower the current ratio, the cost of debt does not affect. Liquidity ratios are used to describe how liquid a company is and the company's ability to settle short-term liabilities using current assets. This ratio is used to measure the company's ability to pay obligations that are due immediately (Kasmir, 2008: 129). In this study, liquidity has no effect on the cost of debt because the sample companies are able to pay off their shortterm debt with their current assets. And if there is a sample company whose short-term debt cannot be covered by current assets, this does not increase the cost of debt, because the sample company's equity still tends to be high, so it can be covered by equity.

\section{The Effect of Leverage on the Cost of Debt}

The test results show that liquidity has a positive effect on the cost of debt. This means that the higher the debt to equity ratio, the higher the cost of debt, on the other hand, the lower the debt to equity ratio, the lower the cost of debt. This is because the sample companies that use debt have obligations for interest expenses and loan principal expenses. The use of debt (external financing) has a large enough risk of not repaying the debt, so the use of debt needs to pay attention to the company's ability to generate profits. Leverage can be understood as an estimator of the risks inherent in a company, meaning that greater leverage indicates greater investment risk Prasetyorini, 2013). The results of this study are in line with the research of Awaloedin dan Nugroho (2019) where the results show that the debt ratio has a positive effect on the cost of debt. 


\section{The Effect of Managerial Ownership on the Cost of Debt}

The test results show managerial ownership has no effect on cost of debt. This means that the higher or lower the managerial ownership does not affect the cost of debt. This is because the existence of managerial ownership in the ownership of company shares should provide an incentive for management to improve its performance. However, the proportion of managerial ownership that tends to be small causes management to feel reluctant to work as much as possible. In addition, this is because management does not have control in determining debt policy because many are controlled by the majority owner

\section{The Effect of Institutional Ownership on the Cost of Debt}

The test results show that institutional ownership has no effect on the cost of debt. That is, the higher or lower institutional ownership does not affect the cost of debt. This can be due to institutional monitoring that tends not to influence creditors' decisions in determining the company's cost of debt. The existence of institutional ownership in a company is considered to provide monitoring measures against the management. However, if this is not accompanied by serious actions in applying the principles of good corporate governance, there will be a lot of ownership

\section{The Effect of Independent Commissioners on the Cost of Debt}

The test results show that the independent commissioner has no effect on the cost of debt. This means that the higher or lower the independent commissioner, the cost of debt does not affect. This is because the existence of independent commissioners by companies may only be done for regulatory compliance but not intended to enforce good corporate governance (GCG) within the company. So the role of independent commissioners in creating transparency cannot be seen by creditors (Juniarti \& Sentosa, 2009). The existence of independent commissioners in a company is considered quite important. However, this is not accompanied by any serious actions in implementing the principles of good corporate governance.

\section{Conclusion}

Based on the results of the analysis and discussion described in the previous chapter, the conclusions of this study are as follows: 

a. Profitability does not affect the cost of debt.
b. Liquidity has no effect on the cost of debt.
c. Leverage has a positive effect on the cost of debt.
d. Managerial ownership has no effect on cost of debt.
e. Institutional ownership does not affect the cost of debt.
f. The Independent Commissioner has no effect on the cost of debt.

\section{Suggestions}

In the research that has been done, there are still several limitations. Based on the results of the conclusions, there are suggestions that can be given, including:

1. For further researchers, because the results of research on Profitability, Liquidity, managerial ownership, institutional ownership, and independent commissioners show that the company does not experience the effect of cost of debt on the sample that has been carried out, it is recommended to re-test because it is not in accordance with the theory applies. Further researchers can also increase the number of research samples or compare manufacturing companies with other sub-sectors such as the food and beverage subsector, or even compare one sector with several companies between countries.

2. For companies, it is expected to pay attention to factors that can lead to high cost of debt, so if there is an indication of increasing cost of debt the company can quickly take action to improve the company's financial condition.

\section{BIBLIOGRAPHY}

Agustina, S. (2013). Pengaruh Profitabilitas dan Pengungkapan Corporate Social Responsibility Terhadap Nilai Perusahaan. Jurnal Akuntansi Ejournal.Unp, 1.

Ashbaugh-Skaife, H., Collins, D. W., \& LaFond, R. (2006). The effects of corporate governance on firms' credit ratings. Journal of Accounting and Economics, 42(1-2), 203 243. https://doi.org/10.1016/j.jacceco.2006.02.003

Ashkhabi, I. R. (2015). Pengaruh Corporate Governance, Struktur Kepemilikan Perusahaan Dan Ukuran Perusahaan Terhadap Biaya Utang. Accounting Analysis Journal, 4(3), 1-8. https://doi.org/10.15294/aaj.v4i3.8304

Awaloedin, D. T., \& Nugroho, R. (2019). PENGARUH UKURAN PERUSAHAAN RASIO UTANG DAN UMUR PERUSAHAAN TERHADAP BIAYA UTANG (Studi pada 
Perusahaan Manufaktur yang Terdaftar di Bursa Efek Indonesia tahun 2015-2017). Jurnal Rekayasa Informasi, 8(1), 52-69.

D, N. P. W. P., \& Suartana, I. W. (2014). PENGARUH KEPEMILIKAN MANAJERIAL DAN KEPEMILIKAN INSTITUSIONAL PADA NILAI PERUSAHAAN. 3, 575-590.

Hanifah, O. E., \& Purwanto, A. (2013). PENGARUH STRUKTUR CORPORATE GOVERNANCE DAN FINANCIAL INDICATORS TERHADAP KONDISI FINANCIAL DISTRESS ( Studi Pada Perusahaan Manufaktur yang Terdaftar di Bursa. Diponegoro Journal of Accounting, 2, 1-15.

Hery. (2015). Analisis Laporan Keuangan (1st ed.). Yogyakarta: Center For Academic Publishing Services.

Jensen, M. C., \& Meckling, W. H. (1976). Theory of the Firm: Managerial. Journal of Financial Economics, 3, 305-360. https://doi.org/http://dx.doi.org/10.1016/0304405X(76)90026-X

Juniarti, \& Sentosa, A. A. (2009). Pengaruh Good Corporate Governance, Voluntary Disclosure terhadap Biaya Hutang (Costs of Debt). Jurnal Akuntansi Dan Keuangan, 11(2), 88-100. https://doi.org/10.9744/jak.11.2.pp.88-100

Kistiah, R., \& Mudjiyanti, R. (2014). Pengaruh Good Corporate Governance, Kualitas Audit, Voluntary Disclosure Terhadap Cost of Debt Pada Perusahaan Manufaktur Yang Terdaftar Di Bei Tahun 2010-2013. Kompartemen: Jurnal Ilmiah Akuntansi, XII(01), 4968. https://doi.org/10.30595/kompartemen.v12i1.1385

Meiriasari, V. (2017). Pengaruh Corporate Governance , Kepemilikan Keluarga , Kepemilikan Institusional Dan Ukuran Perusahaan ( Firm Size ) Terhadap Biaya Utang. Jurnal Ilmiah Ekonomi Global Masa Kini, 8(01), 28-34.

Nur, E., \& Yuyetta, A. (2019). Analisis Pengaruh Mekanisme Corporate Governance Terhadap Probabilitas Terjadinya Financial Distress. Diponegoro Journal of Accounting, $8(3), 1-11$.

Pernamasari, R. (2018). Penerapan Good Corporate Governance dan Earning Management terhadap Biaya Hutang pada Perusahaan BUMN Listing CGPI 2010 - 2012. Jurnal Profita, 11(1), 067. https://doi.org/10.22441/profita.v11.01.005

Prasetyorini, B. F. (2013). Pengaruh Ukuran Perusahaan, Leverage, Price Earning Ratio, dan Profitabilitas terhadap Nilai Perusahaan. Jurnal Ilmu Manajemen, 1 . 
Randa, F., \& Solon, A. (2012). Pengaruh Modal Intelektual Terhadap Nilai Perusahaan (Studi Empiris Pada Perusahaan Manufaktur Yang Terdaftar Di Bursa Efek Indonesia). Jurnal Sistem Informasi Manajemen Dan Akuntansi, 10(1), 24-47.

Saputra, M., \& Faizal, M. (2016). The Influence of Corporate Governance Perception Index, Managerial Ownership, Government Ownership and Sales Growth on Cost of Debt (Study in Non-Financial Companies Listed on IDX Year 2011-2014). Journal of Research in Business, Economics and Management, 6(2), 845-857. Retrieved from www.scitecresearch.com/journals/index.php/jrbem/indexwww.scitecresearch.com

Septian, M., \& Panggabean, R. (2017). Faktor-Faktor yang Mempengarahui Biaya Utang... XXII(01), 37-51.

Sherly, E. N., \& Fitria, D. (2019). PENGARUH PENGHINDARAN PAJAK, KEPEMILIKAN INSTITUSIONAL, DAN PROFITABILITAS TERHADAP BIAYA HUTANG (Studi Empiris Pada Perusahaan Manufaktur Yang Terdaftar Di BEI Periode 2011-2015). EKOMBIS REVIEW: Jurnal Ilmiah Ekonomi Dan Bisnis, 7(1), 58-69. https://doi.org/10.37676/ekombis.v7i1.701

Swissia, P., \& Purba, B. (2018). Pengaruh Struktur Kepemilikan Institusional, Kepemilikan Manajerial, Kepemilikan Keluarga, Pengungkapan Sukarela, dan Leverage Terhadap Biaya Utang. Jurnal Akuntansi Dan Keuangan, 9(2), 42-65.

Yunita, N. (2012). Pengaruh Corporate Governance Terhadap Voluntary Disclosure dan Biaya Hutang. Jurnal Ilmiah Mahasiswa Akuntansi, vol 1(1), 90-96. 